\title{
Impact of applying organic fertilizers on nutrient content of soil and lettuce plants, yield quality and benefit-cost ratio under water stress conditions
}

\author{
Dalia Ahmed Abd El-Fattah1, Fadl Abd-Elhamid Hashem¹, Shaimaa Hassan Abd-Elrahman²* \\ ${ }^{1}$ Central Laboratory for Agricultural Climate 12411, Agricultural Research Center, Egypt \\ ${ }^{2}$ Soil and Water Department, Faculty of Agriculture 11241, Ain Shams University, Egypt
}

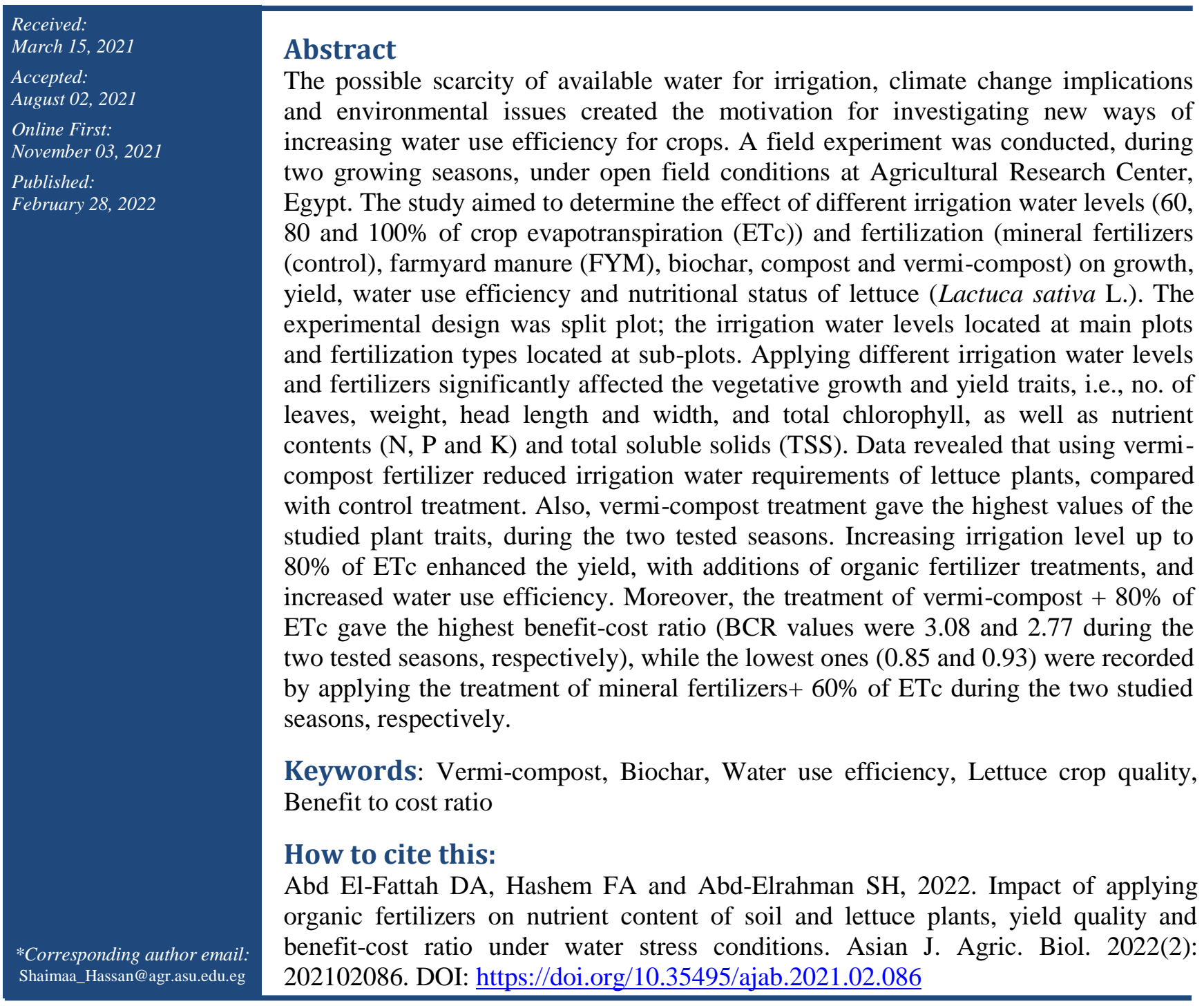

This is an Open Access article distributed under the terms of the Creative Commons Attribution 3.0 License. (https://creativecommons.org/licenses/by/3.0), which permits unrestricted use, distribution, and reproduction in any medium, provided the original work is properly cited. 


\section{Introduction}

Water scarcity is one of the most limiting factors in agriculture worldwide (Hashem and Abd-Elrahman, 2016). Strategies to raise the efficiency of irrigation water are based on two approaches, technological and biological. Technological methods include using of developed irrigation systems and schedule irrigation frequencies. Biological approach includes breeding drought tolerant crop genotypes. Many of vegetable crops are shallow rooted like lettuce, and therefore sensitive to water scarcity (Kere et al., 2003).

Although vegetable production has a high value product, it is a high-cost enterprise. So, many farmers search for having available water for irrigation with enough to ensure against drought. There are many potential benefits from irrigating vegetables, e.g., improving plant growth, increasing yield, and enhancing crop quality (Hashem and Abd-Elrahman, 2016). As water availability became scarcer and increases cost for irrigation, followed technological methods need to be more precise (Chaichi et al., 2020).

Applications of different organic fertilizers and reuse of organic plant residues have remarkable impacts on yield and quality of lettuce (Lactuca sativa L.) and especially its content of nutrients, besides improving soil-water holding capacity and nutrients availability as well as their buffering act on the environment. One of the most common organic fertilizers that added to the agricultural soils is compost. It contains several necessary nutrients and improves soil physical and chemical properties. Compost is a valuable product that improves organic matter content, nutrient availability, water holding capacity and aeration, and decreases bulk density of soil (Mostafa et al., 2019). Also, vermi-compost contains nutrients in forms that are readily available to be absorbed by plants such as $\mathrm{N}, \mathrm{P}, \mathrm{K}, \mathrm{Ca}$ and $\mathrm{Mg}$. Vermi-compost has a great potential in the agricultural industries as a good media for plant growth. It improves seeds germination and enhances rates of seedling development (Abdrabbo et al., 2015; Hashem and Abd-Elrahman, 2016). Moreover, applying biochar for soil restoration and biofertilization has increasingly received concern as low-cost and ecofriendly amendment (Lone et al., 2015; Ibn Ferjani et al., 2020). Several studies have reported the role of biochar in carbon sequestration in soil, and therefore contributing to the mitigation of climate change impacts (Soong et al., 2017; Elsharkawi et al., 2018; Han et al., 2020). In addition, biochar has been used as a remediation tool by limiting bioavailability of heavy metals and pesticides (Khorram et al., 2016). Also, biochar has a positive effect on soil aggregates and regulating soil-water, which may promote plant growth (Obia et al., 2016; El-Bassi et al., 2021).

For sustainable agricultural production, increasing the water use efficiency and reuse the organic materials are playing an important role under the climate change impacts, i.e., water scarcity, high temperature, high evapotranspiration, extreme weather events, etc..., in addition to making use of agricultural residues to store carbon in the soil. Thus, the main objectives of this study are to investigate the influence of organic fertilizers and water requirements on some soil chemical characteristics and growth, yield quality and water use efficiency of iceberg lettuce, compared to use of mineral fertilizers. Economic study was maintained.

\section{Material and Methods}

To assess the effect of different irrigation water levels and fertilizers on some soil chemical characteristics, and growth, yield, water use efficiency and nutritional status of lettuce (Lactuca sativa L.), a field experiment was conducted during the two successive winter seasons of 2018 and 2019 at Dokki protected cultivation experimental site, Central Laboratory for Agricultural Climate, Agricultural Research Center, at Giza Governorate, Egypt. The meteorological data of the experimental site during the two studied seasons are shown in Table 1.

\section{Plant material}

Seeds of iceberg lettuce (Lactuca sativa var. capitata $c v$. Chianti) were sown on February 25, 2018, and February 24, 2019, respectively, in polystyrene trays. After 4 weeks from sowing, the transplants were cultivated in the open field. Lettuce seedlings were planted in 3 beds ( $80 \mathrm{~cm}$ raise) with 2 rows in each bed $(25 \mathrm{~cm}$ apart $)$ and the distance between the plants in each row was $30 \mathrm{~cm}$. 
Dalia Ahmed Abd El-Fattah et al.

Table-1: Meteorological data of Dokki protected cultivation experimental site during lettuce growing season in 2018 and 2019.

\begin{tabular}{|c|c|c|c|c|c|c|c|c|c|c|c|c|}
\hline \multirow{3}{*}{ Weeks* } & \multicolumn{6}{|c|}{ Temperature $\left({ }^{\circ} \mathrm{C}\right)$} & \multirow{2}{*}{\multicolumn{2}{|c|}{$\begin{array}{l}\text { SRAD }^{* *} \\
\left(\mathrm{MJ} / \mathrm{m}^{2} / \text { day }\right)\end{array}$}} & \multirow{2}{*}{\multicolumn{2}{|c|}{$\frac{\mathrm{RH}^{* * * *}}{(\%)}$}} & \multirow{2}{*}{\multicolumn{2}{|c|}{$\begin{array}{l}\text { Wind Speed } \\
(\mathrm{m} / \mathrm{s})\end{array}$}} \\
\hline & \multicolumn{2}{|l|}{ Max } & \multicolumn{2}{|l|}{ Min } & \multicolumn{2}{|l|}{ Mean } & & & & & & \\
\hline & 2018 & 2019 & 2018 & 2019 & 2018 & 2019 & 2018 & 2019 & 2018 & 2019 & 2018 & 2019 \\
\hline 1 & 18.0 & 14.1 & 10.3 & 7.94 & 14.1 & 11.0 & 20.1 & 14.3 & 52.5 & 50.2 & 3.17 & 2.70 \\
\hline 2 & 16.3 & 14.2 & 11.2 & 7.70 & 13.7 & 11.0 & 16.5 & 12.2 & 51.0 & 49.0 & 3.49 & 2.36 \\
\hline 3 & 19.2 & 14.0 & 12.3 & 8.27 & 15.7 & 11.1 & 20.3 & 13.3 & 47.3 & 45.9 & 2.49 & 2.44 \\
\hline 4 & 19.8 & 15.3 & 12.9 & 8.79 & 16.4 & 12.1 & 21.3 & 15.8 & 46.5 & 43.7 & 3.23 & 1.98 \\
\hline 5 & 17.5 & 17.4 & 10.3 & 9.42 & 13.9 & 13.4 & 23.0 & 18.8 & 48.6 & 48.1 & 3.31 & 2.43 \\
\hline 6 & 22.6 & 17.9 & 13.7 & 11.2 & 18.1 & 14.6 & 25.2 & 15.7 & 36.2 & 34.1 & 3.34 & 3.40 \\
\hline 7 & 24.3 & 25.4 & 16.7 & 9.04 & 20.5 & 17.2 & 22.8 & 18.2 & 31.5 & 32.4 & 3.10 & 3.00 \\
\hline 8 & 22.7 & 23.4 & 15.1 & 10.3 & 18.9 & 16.8 & 26.0 & 21.6 & 34.6 & 35.1 & 2.75 & 2.74 \\
\hline
\end{tabular}

\section{Process of composting, vermi-composting, and biochar}

The organic mixtures (agricultural residues and cattle manure, $4: 1)$ were used to make the compost heap with size $2.5 \mathrm{~m}$ length $\times 1.25 \mathrm{~m}$ width $\times 0.75 \mathrm{~m}$ height, according to the steps that were described by Hashem and Abd-Elrahman (2016). Earthworms with different species were used in the vermi-composting bins. Worm length; 10-120 mm and worm diameter; $0.5-5 \mathrm{~mm}$. The input raw materials of vermicomposting included vegetable and fruit wastes + cattle manure + shredded papers $(2: 2: 1)$, according to Abdrabbo et al. (2015) and Hashem and AbdElrahman (2016). These processes were conducted during the summer seasons of (2017 and 2018) and took approximately 4 months in the two tested seasons. The biochar used in the experiment, obtained from the biomass of agricultural residues, through a slow pyrolysis process at a temperature of $420^{\circ} \mathrm{C}$ in a pilot-scale electric pyrolyzer with a maximum capacity of $10 \mathrm{~kg}$ of raw materials per batch. Chemical composition of the different tested organic fertilizers is tabulated (Table 2).

\section{The field experiment}

The experiment was designed in a split plot arrangement with three replications. The treatments comprised three irrigation water levels, i.e., 60, 80 and $100 \%$ of crop evapotranspiration (ETc) in main plots, and five fertilizer treatments (mineral fertilizers (control), farmyard manure (FYM), biochar, compost, and vermi-compost) in sub-plots.

Table-2. Chemical composition of the tested organic fertilizers.

\begin{tabular}{|c|c|c|c|c|c|}
\hline \multirow{2}{*}{$\begin{array}{c}\text { Organic } \\
\text { fertilizer }\end{array}$} & \multicolumn{4}{|c|}{ Nutrient percentage (\%) } & \multirow{2}{*}{$\begin{array}{c}\text { C/N } \\
\text { ratio }\end{array}$} \\
\cline { 2 - 5 } & $\mathbf{N}$ & $\mathbf{P}$ & $\mathbf{K}$ & $\mathbf{C}$ & \\
\hline $\begin{array}{c}\text { Farmyard } \\
\text { manure }\end{array}$ & 1.68 & 0.55 & 1.09 & 15.6 & 9.29 \\
\hline Vermicompost & 1.77 & 0.76 & 1.56 & 17.8 & 10.1 \\
\hline Compost & 1.73 & 0.55 & 1.31 & 17.2 & 9.94 \\
\hline Biochar & 1.46 & 0.51 & 1.38 & 18.7 & 12.8 \\
\hline
\end{tabular}

The organic treatments were applied to the soil before lettuce transplanting by 1 week after raising the beds. The organic fertilizers were mixed with the soil in the beds at a rate of $24 \mathrm{Mg}$ (ton) $\mathrm{ha}^{-1}$. Regarding the mineral fertilizers (control treatment), lettuce plants subjected to this treatment received the recommended doses of $\mathrm{N}, \mathrm{P}$ and $\mathrm{K}$ fertilizers according to the Egyptian Ministry of Agriculture, i.e., ordinary superphosphate $15.5 \% \mathrm{P}_{2} \mathrm{O}_{5}$ was added to the soil before one week from cultivation, during raising the beds, at a rate of $37.2 \mathrm{~kg} \mathrm{P}_{2} \mathrm{O}_{5} \mathrm{ha}^{-1}$. Ammonium sulfate $21 \% \mathrm{~N}$ and potassium sulfate $48 \% \mathrm{~K}_{2} \mathrm{O}$ were applied, at a rate of $75.6 \mathrm{~kg} \mathrm{~N} \mathrm{ha}^{-1}$ and $115 \mathrm{~kg} \mathrm{~K}_{2} \mathrm{O} \mathrm{ha}{ }^{-1}$, in two batches the first one was after 15 days from seedlings transplant, and the other one was after 15 days from adding the first batch. 
Dalia Ahmed Abd El-Fattah et al.

Table-3: Some initial physical and chemical properties of the studied soil $(0-15 \mathrm{~cm})$.

\begin{tabular}{|c|c|c|c|c|c|c|c|c|c|}
\hline $\begin{array}{c}\text { Sand } \\
\%\end{array}$ & $\begin{array}{c}\text { Silt } \\
\%\end{array}$ & $\begin{array}{c}\text { Clay } \\
\%\end{array}$ & $\begin{array}{c}\text { Textural } \\
\text { class }\end{array}$ & $\begin{array}{c}\mathrm{SP} \\
\%\end{array}$ & $\begin{array}{c}\mathrm{FC} \\
\%\end{array}$ & $\begin{array}{c}\mathrm{WP} \\
\%\end{array}$ & $\begin{array}{c}\mathrm{BD} \\
\mathrm{Mg} \mathrm{m}^{-3}\end{array}$ & $\begin{array}{c}\mathrm{CaCO} \\
\%\end{array}$ & $\begin{array}{c}\mathrm{OM}_{3} \\
\%\end{array}$ \\
\hline 16.9 & 30.8 & 52.3 & Clay & 87.9 & 62.1 & 27.8 & 1.35 & 5.61 & 0.81 \\
\hline $\begin{array}{c}\mathrm{pH} \\
(1: 2.5)\end{array}$ & $\begin{array}{c}\mathrm{EC}_{\mathrm{e}}, \\
\mathrm{dS} \mathrm{m}\end{array}$ & $\begin{array}{c}\mathrm{Ca}^{2+} \\
\mathrm{mmolc} \mathrm{L}^{-1}\end{array}$ & $\begin{array}{c}\mathrm{Mg}^{2+} \\
\mathrm{mmolc} \mathrm{L}\end{array}$ & $\begin{array}{c}\mathrm{Na}^{+} \\
\mathrm{mmolc} \mathrm{L} \mathrm{L}^{-1}\end{array}$ & $\begin{array}{c}\mathrm{K}^{+} \\
\mathrm{mmolc} \mathrm{L}^{-1}\end{array}$ & $\begin{array}{c}\mathrm{CO}_{3}{ }^{2-} \\
\mathrm{mmolc} \mathrm{L}^{-1}\end{array}$ & $\begin{array}{c}\mathrm{HCO}_{3}^{-} \\
\mathrm{mmolc} \mathrm{L}^{-1}\end{array}$ & $\begin{array}{c}\mathrm{Cl}^{-} \\
\mathrm{mmolc} \mathrm{L}^{-1}\end{array}$ & $\begin{array}{c}\mathrm{SO}_{4}{ }^{2-} \\
\mathrm{mmolc} \mathrm{L}^{-1}\end{array}$ \\
\hline 7.64 & 2.69 & 10.9 & 7.74 & 11.6 & 5.98 & n.d & 7.05 & 12.9 & 13.9 \\
\hline
\end{tabular}

*n.d means not detected.

The plot area was $12 \mathrm{~m}^{2}$ ( $6 \mathrm{~m}$ length $\times 2 \mathrm{~m}$ width). Flow meter was installed for each irrigation level treatment; 2 $\mathrm{m}$ were left between each two irrigation levels. Lettuce plants were irrigated using drippers of $4 \mathrm{~L} \mathrm{~h}^{-1}$ capacity. Some physical and chemical characteristics of the studied soil $(0-15 \mathrm{~cm})$ were determined, before cultivation, by the standard methods outlined by Page et al. (1982) and Klute (1986) and the obtained results are presented in Table 3.

\section{Estimation of water requirements}

The crop evapotranspiration, ETc, was calculated as follows according to FAO (2012): $\mathrm{ET}_{\mathrm{c}}=\mathrm{K}_{\mathrm{c}} * \mathrm{ET}_{\mathrm{o}}$ Where: $\mathrm{ET}_{\mathrm{c}}$ crop evapotranspiration $\left(\mathrm{mm} \mathrm{d}^{-1}\right), \mathrm{K}_{\mathrm{c}}$ crop coefficient (dimensionless), $\mathrm{ET}_{\mathrm{o}}$ reference crop evapotranspiration $\left(\mathrm{mm} \mathrm{d}^{-1}\right)$.

The total applied water volumes of $60,80,100 \%$ of ETc in the experimental area were 2486, 3314 and $4142 \mathrm{~m}^{3} \mathrm{ha}^{-1}$, respectively, during the tested season of 2018 and 2596, 3461 and $4327 \mathrm{~m}^{3} \mathrm{ha}^{-1}$, respectively, during the tested season of 2019.

The water use efficiency (WUE, $\mathrm{kg} \mathrm{m}^{-3}$ ) was calculated according to FAO (1982) as follows: The ratio of crop yield ( $\mathrm{Y}, \mathrm{kg}$ ) to the total amount of irrigation water used for the growing season (IR, $\mathrm{m}^{3}$ ). Crop management practices were in line with standard recommendations for farmers.

\section{Measurements}

Samples of 3 plants of each experimental plot were taken at 55 days from the cultivation date, to determine growth parameters at harvest as follows: No. of leaves per plant, yield weigh, head length, head width and total chlorophyll (SPAD). The SPAD value was estimated as reported by Minolta (1989).

For $\mathrm{N}, \mathrm{P}$ and $\mathrm{K}$ determinations in leaves, 3 plant samples of each plot were dried at $65^{\circ} \mathrm{C}$ in an air forced oven for $48 \mathrm{~h}$. Dried leaves were digested by a mixture of $\mathrm{H}_{2} \mathrm{SO}_{4} / \mathrm{H}_{2} \mathrm{O}_{2}$ according to the method described by Page et al. (1982). Total $\mathrm{N}$ was determined using Kjeldahl method according to the procedure described by Chapman and Pratt (1961).
The $\mathrm{P}$ content was determined spectrophotometrically as outlined by Watanabe and Olsen (1965). The K content was determined using Flame photometer as described by Chapman and Pratt (1961). Total soluble solids (TSS) in the juice extracted from leaves expressed as Brix value were determined by digital refractometer (Magwaza and Opara, 2015).

Soil samples were collected after plant harvest at 0$15 \mathrm{~cm}$ depth. The collected samples were air dried, crushed, and sieved through a $2 \mathrm{~mm}$ sieve and prepared for chemical determinations of available concentrations of $\mathrm{N}, \mathrm{P}$ and $\mathrm{K}$ as well as OM content in soil according to the methods that described by Page et al. (1982).

According to Cimmyt (1988), the benefit-cost analysis (BCA) as the most appropriate economic analysis tool for decision makers was chosen. The benefit-cost ratio (BCR) for numerous projects can be compared to each other to determine which project has a higher economic return, with higher BCR's indicate higher return.

\section{Statistical analysis}

The obtained data were statistically analyzed using SAS software package. The means that were significant were separated using Duncan's multiple range test at $P \leq 0.05$ (SAS, 2006).

\section{Results and Discussion}

\section{Soil chemical characteristics}

Available N, P and K for the investigated soil (Table 4) showed that the treatment of vermi-compost increased soil content of these nutrients compared to other treatments, with significant differences between mineral fertilizer treatments and those of organic ones. This may be due to that vermi-compost is rich in those nutrients (see Table 2). Munnoli et al. (2010) reported that applying vermi-compost to the soil modified its physico-chemical properties, water holding capacity and infiltration, as well as it enhanced soil fertility and soil microorganisms. 
Dalia Ahmed Abd El-Fattah et al.

Table-4: Effect of different irrigation levels and fertilizers on some soil chemical characteristics $(0-15 \mathrm{~cm})$, after plant harvesting during the two studied seasons of 2018 and 2019.

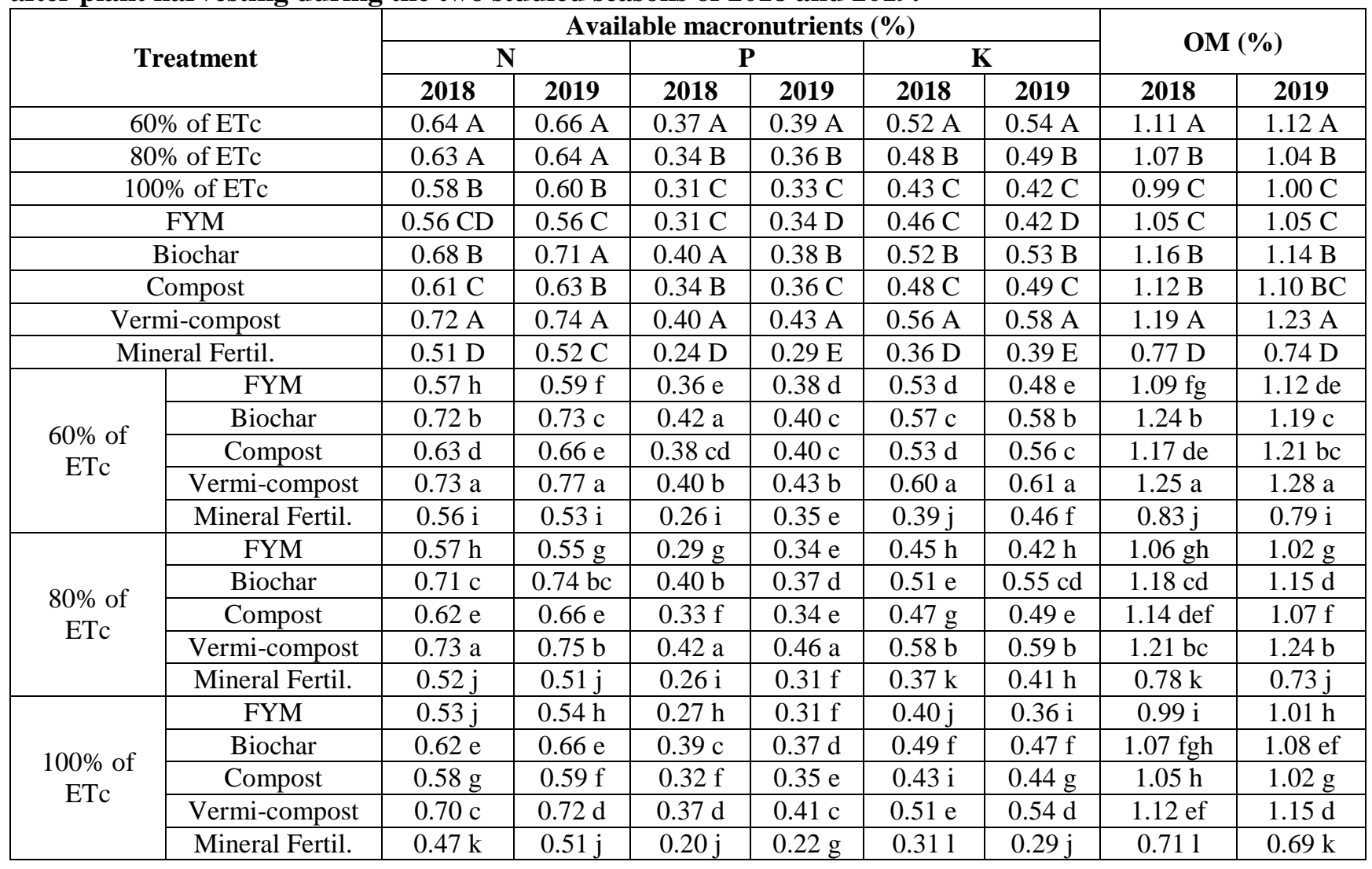

Increasing irrigation water level led to decrease in the available amount of $\mathrm{N}, \mathrm{P}$ and $\mathrm{K}$ in soil during the two studied seasons; possibly due to their consequent leachability out of soil profile. Regarding the interaction among treatments, the results showed that treatment of $60 \%$ of ETc combined with vermicompost gave the highest values of nutrient contents in the studied soil. Logically, application of organic fertilizers increased soil organic matter content compared to mineral fertilizers treatment (control), the highest value being obtained by vermi-compost treatment. Increasing irrigation water level decreased OM content of the studied soil; the interaction among treatments showed that the treatment of $60 \%$ of ETc combined with vermi-compost gave the highest value of soil OM content; $100 \%$ of ETc combined with mineral fertilizers treatment gave the lowest corresponding one. Similar trend was found during the second season, with almost higher values compared to the first season; may be due to the continued application of the studied treatments. Opposite trend was obvious (the first season was higher than the second one) with application of mineral fertilizers especially about the effect on OM content in the studied soil. These results are in line with those obtained by Hashem and Abd-Elrahman (2016) concerning the effect of vermi-compost tea and compost tea combined with different irrigation water levels in this respect. Also, the results obtained herein agreed with those obtained by Han et al. (2020) concerning the effect of biochar on increasing soil organic carbon (SOC) and consequently soil organic matter (SOM) content.

\section{Vegetative growth and yield traits}

Data in Table 5 showed the effect of different irrigation water levels and fertilizers on vegetative growth and yield traits of lettuce plants, i.e., no. of leaves per plant, yield weigh, head length, head width and chlorophyll content, during the two studied seasons of 2018 and 2019. Regarding the effect of the irrigation levels, the treatment of $80 \%$ of ETc gave the highest no. of leaves per plant, yield weigh and head width, followed by the treatment of $100 \%$ of ETc. There was no significant difference between the treatment of $80 \%$ and $100 \%$ of ETc in their effect on 
head length. Head length is a quality characteristic, the shorter the better. On the opposite trend, chlorophyll content was higher under low irrigation level $(60 \%$ of ETc) during the two studied seasons, and this is an indicator that plants suffer from water stress. These results agree with those outlined by Abdrabbo et al. (2015) on cabbage, and Chaichi et al. (2020) on lettuce under different irrigation levels. They demonstrated that increasing irrigation level decreases the concentration of nutrients and chlorophyll in plant leaves, due to dilution effect.

Regarding the effect of different fertilizers application, data in Table 5 showed that the treatment of vermi-compost gave the highest values of no. of leaves per plant, yield weigh, head length and width, followed by biochar and mineral fertilizers, respectively. On contrary, application of mineral fertilizers led to increase chlorophyll content, as compared to organic fertilizers. These results agree with those found by Abdrabbo et al. (2015) on the effect of organic fertilizers on enhancing plants growth and yield, as compared to mineral fertilizers.

The interaction between irrigation water levels and fertilizer treatments was of significant effect on vegetative growth and yield traits during the two studied seasons (Table 5). The highest values of number of leaves per plant, yield weigh and head width were achieved due to the treatment of $80 \%$ of ETc combined with vermi-compost followed by $80 \%$ of ETc combined with biochar treatment. Regarding the head length of lettuce, the treatment of $100 \%$ of ETc combined with vermi-compost gave the highest value. Chlorophyll content had another trend; the highest value was obtained by the treatment of $60 \%$ of ETc combined with mineral fertilizers, during the two tested seasons.

Table-5. Effect of different irrigation levels and fertilizers on vegetative growth and yield traits of lettuce plants during the two studied seasons of 2018 and 2019.

\begin{tabular}{|c|c|c|c|c|c|c|c|c|c|c|c|}
\hline \multirow{3}{*}{\multicolumn{2}{|c|}{ Treatment }} & \multirow{2}{*}{\multicolumn{2}{|c|}{ No. of leaves/plant }} & \multirow{2}{*}{\multicolumn{2}{|c|}{$\frac{\text { Yield }}{(\mathrm{kg} / \text { plot area*) }}$}} & \multirow{2}{*}{\multicolumn{2}{|c|}{$\begin{array}{c}\text { Head length } \\
(\mathrm{cm})\end{array}$}} & \multirow{2}{*}{\multicolumn{2}{|c|}{$\frac{\text { Head width }}{(\mathrm{cm})}$}} & \multirow{2}{*}{\multicolumn{2}{|c|}{$\begin{array}{c}\text { Chlorophyll } \\
\text { (SPAD) }\end{array}$}} \\
\hline & & & & & & & & & & & \\
\hline & & 2018 & 2019 & 2018 & 2019 & 2018 & 2019 & 2018 & 2019 & 2018 & 2019 \\
\hline \multicolumn{2}{|c|}{$60 \%$ of ETc } & $29.1 \mathrm{C}$ & $27.3 \mathrm{C}$ & $23.9 \mathrm{~B}$ & $24.8 \mathrm{C}$ & $13.2 \mathrm{~B}$ & $14.2 \mathrm{~B}$ & $27.7 \mathrm{~B}$ & $28.9 \mathrm{C}$ & $46.2 \mathrm{~A}$ & $47.1 \mathrm{~A}$ \\
\hline \multicolumn{2}{|c|}{$80 \%$ of ETc } & $36.5 \mathrm{~A}$ & $35.7 \mathrm{~A}$ & $38.3 \mathrm{~A}$ & $36.4 \mathrm{~A}$ & $15.5 \mathrm{~A}$ & $15.9 \mathrm{~A}$ & $34.1 \mathrm{~A}$ & $44.1 \mathrm{~A}$ & $39.1 \mathrm{~B}$ & $42.1 \mathrm{~B}$ \\
\hline \multicolumn{2}{|c|}{$100 \%$ of ETc } & $35.1 \mathrm{~B}$ & $32.6 \mathrm{~B}$ & $37.9 \mathrm{~A}$ & $30.9 \mathrm{~B}$ & $15.8 \mathrm{~A}$ & $16.1 \mathrm{~A}$ & $33.7 \mathrm{~A}$ & $38.6 \mathrm{~B}$ & $35.1 \mathrm{C}$ & $35.7 \mathrm{C}$ \\
\hline \multicolumn{2}{|l|}{ FYM } & $28.7 \mathrm{E}$ & $28.1 \mathrm{D}$ & $23.5 \mathrm{E}$ & $22.0 \mathrm{D}$ & $12.4 \mathrm{D}$ & $12.7 \mathrm{D}$ & $24.9 \mathrm{D}$ & $31.5 \mathrm{E}$ & $35.5 \mathrm{D}$ & $35.4 \mathrm{E}$ \\
\hline \multicolumn{2}{|c|}{ Biochar } & $35.5 \mathrm{~B}$ & $33.2 \mathrm{~B}$ & $37.4 \mathrm{~B}$ & $34.7 \mathrm{~B}$ & $15.4 \mathrm{~B}$ & $16.7 \mathrm{AB}$ & $33.4 \mathrm{~B}$ & $39.2 \mathrm{~B}$ & $39.6 \mathrm{C}$ & $41.6 \mathrm{C}$ \\
\hline \multicolumn{2}{|c|}{ Compost } & $30.3 \mathrm{D}$ & $30.4 \mathrm{C}$ & $30.7 \mathrm{D}$ & $26.5 \mathrm{C}$ & $13.5 \mathrm{C}$ & $13.8 \mathrm{C}$ & $29.2 \mathrm{C}$ & $33.8 \mathrm{D}$ & $38.2 \mathrm{C}$ & $39.4 \mathrm{D}$ \\
\hline \multicolumn{2}{|c|}{ Vermi-compost } & $39.0 \mathrm{~A}$ & $35.3 \mathrm{~A}$ & $41.3 \mathrm{~A}$ & $36.7 \mathrm{~A}$ & $17.7 \mathrm{~A}$ & $17.6 \mathrm{~A}$ & $39.9 \mathrm{~A}$ & $45.2 \mathrm{~A}$ & $42.5 \mathrm{~B}$ & $45.0 \mathrm{~B}$ \\
\hline \multicolumn{2}{|c|}{ Mineral Fertil. } & $34.3 \mathrm{C}$ & $32.3 \mathrm{~B}$ & $34.0 \mathrm{C}$ & $33.6 \mathrm{~B}$ & $15.2 \mathrm{~B}$ & $16.2 \mathrm{~B}$ & $31.8 \mathrm{~B}$ & $36.1 \mathrm{C}$ & $44.7 \mathrm{~A}$ & $46.9 \mathrm{~A}$ \\
\hline \multirow{5}{*}{$\begin{array}{c}60 \% \\
\text { of } \\
\text { ETc }\end{array}$} & FYM & 23.31 & $22.7 \mathrm{n}$ & $19.8 \mathrm{~m}$ & $18.4 \mathrm{k}$ & 11.51 & $11.3 \mathrm{j}$ & $21.9 \mathrm{k}$ & $25.1 \mathrm{j}$ & $39.5 \mathrm{~g}$ & $42.1 \mathrm{~g}$ \\
\hline & Biochar & $31.7 \mathrm{~h}$ & $29.7 \mathrm{k}$ & $23.1 \mathrm{k}$ & $26.4 \mathrm{~h}$ & $14.3 \mathrm{f}$ & $15.7 \mathrm{de}$ & $29.0 \mathrm{~h}$ & $29.2 \mathrm{~h}$ & $44.4 \mathrm{c}$ & $47.2 \mathrm{~d}$ \\
\hline & Compost & $27.7 \mathrm{k}$ & $26.0 \mathrm{~m}$ & $22.9 \mathrm{kl}$ & $24.0 \mathrm{j}$ & $12.4 \mathrm{k}$ & $12.9 \mathrm{i}$ & $24.8 \mathrm{j}$ & $27.5 \mathrm{i}$ & $40.8 \mathrm{e}$ & $44.8 \mathrm{e}$ \\
\hline & Vermi-compost & $33.0 \mathrm{~g}$ & $30.0 \mathrm{j}$ & $31.5 \mathrm{~h}$ & $30.1 \mathrm{~g}$ & $14.5 \mathrm{e}$ & $15.9 \mathrm{~d}$ & $34.7 \mathrm{de}$ & $33.4 \mathrm{~g}$ & $50.9 \mathrm{~b}$ & $50.4 \mathrm{~b}$ \\
\hline & Mineral Fertil. & $29.7 \mathrm{j}$ & 28.31 & 22.41 & $25.0 \mathrm{i}$ & $13.5 \mathrm{~h}$ & $15.4 \mathrm{e}$ & $28.4 \mathrm{hi}$ & $29.1 \mathrm{~h}$ & $55.2 \mathrm{a}$ & $51.1 \mathrm{a}$ \\
\hline \multirow{5}{*}{$\begin{array}{c}80 \% \\
\text { of } \\
\text { ETc }\end{array}$} & FYM & $31.7 \mathrm{~h}$ & $31.3 \mathrm{~g}$ & $26.6 \mathrm{i}$ & $31.9 \mathrm{f}$ & $12.7 \mathrm{j}$ & $13.4 \mathrm{~h}$ & $25.4 \mathrm{j}$ & $35.4 \mathrm{f}$ & $36.1 \mathrm{i}$ & $36.2 \mathrm{j}$ \\
\hline & Biochar & $39.3 \mathrm{~b}$ & $38.3 \mathrm{~b}$ & $44.7 \mathrm{c}$ & $40.6 \mathrm{~b}$ & $15.8 \mathrm{~d}$ & $17.2 \mathrm{~b}$ & $37.0 \mathrm{c}$ & $49.1 \mathrm{~b}$ & $38.7 \mathrm{~h}$ & $41.2 \mathrm{~h}$ \\
\hline & Compost & $31.7 \mathrm{~h}$ & $34.7 \mathrm{~d}$ & $36.2 \mathrm{f}$ & $30.7 \mathrm{~g}$ & $14.3 \mathrm{f}$ & $14.1 \mathrm{~g}$ & $32.3 \mathrm{f}$ & $38.5 \mathrm{e}$ & $38.6 \mathrm{~h}$ & $41.5 \mathrm{~h}$ \\
\hline & Vermi-compost & $45.3 \mathrm{a}$ & $43.3 \mathrm{a}$ & $46.6 \mathrm{a}$ & $42.6 \mathrm{a}$ & $18.9 \mathrm{~b}$ & $18.3 \mathrm{a}$ & $43.9 \mathrm{a}$ & $58.0 \mathrm{a}$ & $41.6 \mathrm{~d}$ & $43.9 \mathrm{f}$ \\
\hline & Mineral Fertil. & $34.3 \mathrm{f}$ & $31.0 \mathrm{gh}$ & $37.3 \mathrm{e}$ & $36.1 \mathrm{e}$ & $15.9 \mathrm{~d}$ & $16.6 \mathrm{c}$ & $31.8 \mathrm{fg}$ & $39.3 \mathrm{de}$ & $40.4 \mathrm{f}$ & $47.8 \mathrm{c}$ \\
\hline \multirow{5}{*}{$\begin{array}{l}100 \\
\% \text { of } \\
\text { ETc }\end{array}$} & FYM & $31.0 \mathrm{i}$ & $30.3 \mathrm{ij}$ & $23.9 \mathrm{j}$ & 15.71 & $12.9 \mathrm{i}$ & $13.6 \mathrm{~h}$ & $27.5 \mathrm{i}$ & $34.0 \mathrm{~g}$ & 30.91 & 27.91 \\
\hline & Biochar & $35.3 \mathrm{e}$ & $31.7 \mathrm{f}$ & $44.5 \mathrm{c}$ & $37.0 \mathrm{~d}$ & $16.2 \mathrm{c}$ & $17.3 \mathrm{~b}$ & $34.1 \mathrm{e}$ & 39.3 de & $35.7 \mathrm{j}$ & $36.4 \mathrm{j}$ \\
\hline & Compost & $31.7 \mathrm{~h}$ & 30.7 hi & $32.9 \mathrm{~g}$ & $24.7 \mathrm{i}$ & $13.9 \mathrm{~g}$ & $14.4 \mathrm{f}$ & $30.6 \mathrm{~g}$ & $35.4 \mathrm{f}$ & $35.2 \mathrm{k}$ & $32.0 \mathrm{k}$ \\
\hline & Vermi-compost & $38.7 \mathrm{~d}$ & $32.7 \mathrm{e}$ & $45.7 \mathrm{~b}$ & $37.5 \mathrm{~d}$ & $19.7 \mathrm{a}$ & $18.5 \mathrm{a}$ & $41.3 \mathrm{~b}$ & $44.2 \mathrm{c}$ & $35.0 \mathrm{k}$ & $40.5 \mathrm{i}$ \\
\hline & Mineral Fertil. & $39.0 \mathrm{c}$ & $37.7 \mathrm{c}$ & $42.2 \mathrm{~d}$ & $39.8 \mathrm{c}$ & $16.1 \mathrm{c}$ & $16.7 \mathrm{c}$ & $35.2 \mathrm{~d}$ & $39.9 \mathrm{~d}$ & $38.6 \mathrm{~h}$ & $41.9 \mathrm{~g}$ \\
\hline
\end{tabular}

*Plot area $=12 \mathrm{~m}^{2}$. 
Asaduzzaman et al. (2010) found that applying vermicompost led to improve yield compared to the other organic fertilizer sources; because of its effect on improving growth and nutrient uptake. It was obvious that the treatment of $80 \%$ of ETc combined with organic fertilizers gave better results of vegetative growth and yield traits, while the treatment of $100 \%$ of ETc combined with mineral fertilizers gave better results of the same characteristics in lettuce plants. It may refer to the effect of organic fertilizers on enhancing soil-water holding capacity and soil characteristics, so improving crop performance (Mostafa et al., 2019).

\section{Chemical components of plant leaves}

Data in Table 6 showed the influence of different irrigation levels and fertilizers on concentrations of $\mathrm{N}$, $\mathrm{P}$ and $\mathrm{K}$, as well as TSS content in lettuce leaves, during the two studied seasons of 2018 and 2019. Regarding the effect of the irrigation levels, the treatment of $60 \%$ of ETc resulted in the highest average values of the studied parameters, followed by the treatment of $80 \%$ and $100 \%$ of ETc, respectively. This sequence may be due to the dilution effect with increasing irrigation level (Hashem et al., 2014; Hashem and Abd-Elrahman, 2016).

The fertilizer treatments significantly affected the percentages of $\mathrm{N}, \mathrm{P}$ and $\mathrm{K}$ in lettuce leaves (Table 6). Mineral fertilizer applications resulted in the highest average values in plants, followed by vermi-compost and biochar, respectively. The TSS had the same trend; mineral fertilizers treatment gave the highest values. This might occur due to that nutrient in the mineral fertilizers are more readily available, as compared to those of the organic fertilizers slow released (Walker and Bernal, 2004).

Regarding the interaction effect between irrigation levels and fertilizers, the highest concentrations were obtained by the treatment of $60 \%$ of ETc combined with mineral fertilizers. The lowest concentrations were obtained by the treatment of $100 \%$ of ETc combined with FYM. These results are in line with those outlined by Abdrabbo et al. (2015) and Mostafa et al. (2019). Applying proper water quantity allows plants to use water and nutrients from surrounding soil, thus increases water and nutrient use efficiency, and decrease nutrient leaching.

Table-6. Effect of different irrigation levels and fertilizers on chemical components of lettuce leaves during the two studied seasons of 2018 and 2019.

\begin{tabular}{|c|c|c|c|c|c|c|c|c|c|}
\hline \multirow{2}{*}{\multicolumn{2}{|c|}{ Treatment }} & \multirow{2}{*}{\multicolumn{2}{|c|}{ N }} & \multirow{2}{*}{\multicolumn{2}{|c|}{$\begin{array}{l}\mathrm{P} \\
\% \\
\end{array}$}} & \multirow{2}{*}{\multicolumn{2}{|c|}{$\begin{array}{l}\mathrm{K} \\
\%\end{array}$}} & \multirow{2}{*}{\multicolumn{2}{|c|}{$\begin{array}{c}\text { TSS } \\
\text { (Brix) } \\
\end{array}$}} \\
\hline & & & & & & & & & \\
\hline & & 2018 & 2019 & 2018 & 2019 & 2018 & 2019 & 2018 & 2019 \\
\hline \multicolumn{2}{|r|}{$60 \%$ of ETc } & $2.49 \mathrm{~A}$ & $2.65 \mathrm{~A}$ & $0.74 \mathrm{~A}$ & $0.75 \mathrm{~A}$ & $1.69 \mathrm{~A}$ & $1.60 \mathrm{~A}$ & $3.57 \mathrm{~A}$ & $3.52 \mathrm{~A}$ \\
\hline \multicolumn{2}{|r|}{$80 \%$ of ETc } & $2.11 \mathrm{~B}$ & $2.21 \mathrm{~B}$ & $0.67 \mathrm{~B}$ & $0.69 \mathrm{~B}$ & $1.47 \mathrm{~B}$ & $1.22 \mathrm{~B}$ & $3.10 \mathrm{~B}$ & $3.12 \mathrm{~A}$ \\
\hline \multicolumn{2}{|r|}{$100 \%$ of ETc } & $2.03 \mathrm{C}$ & $1.93 \mathrm{C}$ & $0.54 \mathrm{C}$ & $0.56 \mathrm{C}$ & $1.16 \mathrm{C}$ & $1.07 \mathrm{C}$ & $2.68 \mathrm{C}$ & $2.66 \mathrm{~B}$ \\
\hline \multicolumn{2}{|r|}{ FYM } & $2.03 \mathrm{D}$ & $1.95 \mathrm{D}$ & $0.53 \mathrm{D}$ & $0.50 \mathrm{D}$ & $1.13 \mathrm{D}$ & $1.01 \mathrm{D}$ & $2.21 \mathrm{D}$ & $2.56 \mathrm{C}$ \\
\hline \multicolumn{2}{|r|}{ Biochar } & $2.20 \mathrm{~B}$ & $2.25 \mathrm{BC}$ & $0.65 \mathrm{C}$ & $0.69 \mathrm{~B}$ & $1.47 \mathrm{~B}$ & $1.32 \mathrm{BC}$ & $3.10 \mathrm{C}$ & $3.13 \mathrm{~B}$ \\
\hline \multicolumn{2}{|r|}{ Compost } & $2.13 \mathrm{C}$ & $2.17 \mathrm{C}$ & $0.64 \mathrm{C}$ & $0.62 \mathrm{C}$ & $1.29 \mathrm{C}$ & $1.19 \mathrm{C}$ & $3.13 \mathrm{C}$ & $2.98 \mathrm{~B}$ \\
\hline \multicolumn{2}{|c|}{ Vermi-compost } & $2.21 \mathrm{~B}$ & $2.32 \mathrm{~B}$ & $0.71 \mathrm{~B}$ & $0.73 \mathrm{~B}$ & $1.62 \mathrm{~A}$ & $1.41 \mathrm{~B}$ & $3.48 \mathrm{~B}$ & $3.35 \mathrm{~A}$ \\
\hline \multicolumn{2}{|c|}{ Mineral Fertil. } & $2.48 \mathrm{~A}$ & $2.63 \mathrm{~A}$ & $0.76 \mathrm{~A}$ & $0.80 \mathrm{~A}$ & $1.69 \mathrm{~A}$ & $1.57 \mathrm{~A}$ & $3.65 \mathrm{~A}$ & $3.47 \mathrm{~A}$ \\
\hline \multirow{5}{*}{$\begin{array}{c}60 \% \text { of } \\
\text { ETc }\end{array}$} & FYM & $2.15 \mathrm{~g}$ & $2.47 \mathrm{~d}$ & $0.61 \mathrm{~h}$ & $0.57 \mathrm{i}$ & $1.30 \mathrm{f}$ & $1.44 \mathrm{e}$ & $2.94 \mathrm{~h}$ & $2.90 \mathrm{~h}$ \\
\hline & Biochar & $2.55 \mathrm{~b}$ & $2.57 \mathrm{c}$ & $0.72 \mathrm{~d}$ & $0.77 \mathrm{c}$ & $1.70 \mathrm{c}$ & $1.58 \mathrm{c}$ & $3.72 \mathrm{c}$ & $3.65 \mathrm{c}$ \\
\hline & Compost & $2.39 \mathrm{c}$ & $2.48 \mathrm{~cd}$ & $0.71 \mathrm{de}$ & $0.70 \mathrm{e}$ & $1.55 \mathrm{~d}$ & $1.45 \mathrm{e}$ & $3.66 \mathrm{~d}$ & $3.32 \mathrm{e}$ \\
\hline & Vermi-compost & $2.34 \mathrm{~d}$ & $2.68 \mathrm{~b}$ & $0.81 \mathrm{~b}$ & $0.84 \mathrm{~b}$ & $1.92 \mathrm{a}$ & $1.68 \mathrm{~b}$ & $3.75 \mathrm{~b}$ & $3.76 \mathrm{~b}$ \\
\hline & Mineral Fertil. & $3.02 \mathrm{a}$ & $3.07 \mathrm{a}$ & $0.85 \mathrm{a}$ & $0.88 \mathrm{a}$ & $1.98 \mathrm{a}$ & $1.87 \mathrm{a}$ & $3.77 \mathrm{a}$ & $3.94 \mathrm{a}$ \\
\hline \multirow{5}{*}{$\begin{array}{c}80 \% \text { of } \\
\text { ETc }\end{array}$} & FYM & $2.00 \mathrm{i}$ & $1.79 \mathrm{~h}$ & $0.60 \mathrm{i}$ & $0.49 \mathrm{j}$ & $1.13 \mathrm{~g}$ & $0.85 \mathrm{k}$ & $2.02 \mathrm{k}$ & $2.41 \mathrm{k}$ \\
\hline & Biochar & $2.06 \mathrm{~h}$ & $2.19 \mathrm{e}$ & $0.68 \mathrm{f}$ & $0.71 \mathrm{e}$ & $1.46 \mathrm{e}$ & $1.24 \mathrm{~g}$ & $3.14 \mathrm{~g}$ & $3.22 \mathrm{f}$ \\
\hline & Compost & $2.03 \mathrm{~h}$ & $2.06 \mathrm{f}$ & $0.65 \mathrm{~g}$ & $0.65 \mathrm{f}$ & $1.26 \mathrm{f}$ & $1.19 \mathrm{hi}$ & $3.13 \mathrm{~g}$ & $3.07 \mathrm{~g}$ \\
\hline & Vermi-compost & $2.23 \mathrm{e}$ & $2.26 \mathrm{e}$ & $0.70 \mathrm{e}$ & $0.73 \mathrm{~d}$ & $1.68 \mathrm{c}$ & $1.32 \mathrm{f}$ & $3.43 \mathrm{e}$ & $3.49 \mathrm{~d}$ \\
\hline & Mineral Fertil. & $2.22 \mathrm{e}$ & $2.73 \mathrm{~b}$ & $0.75 \mathrm{c}$ & $0.87 \mathrm{a}$ & $1.81 \mathrm{~b}$ & $1.53 \mathrm{~d}$ & $3.76 \mathrm{ab}$ & $3.41 \mathrm{~d}$ \\
\hline \multirow{5}{*}{$\begin{array}{c}100 \% \text { of } \\
\text { ETc }\end{array}$} & FYM & $1.93 \mathrm{k}$ & $1.59 \mathrm{i}$ & $0.37 \mathrm{k}$ & $0.44 \mathrm{k}$ & $0.97 \mathrm{~h}$ & 0.731 & 1.661 & $2.37 \mathrm{k}$ \\
\hline & Biochar & $1.98 \mathrm{ij}$ & $2.00 \mathrm{fg}$ & $0.54 \mathrm{j}$ & $0.60 \mathrm{~h}$ & $1.25 \mathrm{f}$ & $1.15 \mathrm{i}$ & $2.45 \mathrm{j}$ & $2.51 \mathrm{j}$ \\
\hline & Compost & $1.97 \mathrm{j}$ & $1.97 \mathrm{~g}$ & $0.59 \mathrm{i}$ & $0.50 \mathrm{j}$ & $1.05 \mathrm{gh}$ & $0.93 \mathrm{j}$ & $2.61 \mathrm{i}$ & $2.53 \mathrm{j}$ \\
\hline & Vermi-compost & $2.06 \mathrm{~h}$ & $2.03 \mathrm{f}$ & $0.61 \mathrm{~h}$ & $0.63 \mathrm{~g}$ & $1.27 \mathrm{f}$ & $1.23 \mathrm{gh}$ & $3.27 \mathrm{f}$ & $2.80 \mathrm{i}$ \\
\hline & Mineral Fertil. & $2.18 \mathrm{f}$ & $2.09 \mathrm{f}$ & $0.68 \mathrm{f}$ & $0.64 \mathrm{fg}$ & $1.27 \mathrm{f}$ & $1.32 \mathrm{f}$ & $3.41 \mathrm{e}$ & $3.07 \mathrm{~g}$ \\
\hline
\end{tabular}


Dalia Ahmed Abd El-Fattah et al.

Table-7: Water use efficiency of lettuce plants under different irrigation water levels and fertilizers in the two seasons of 2018 and 2019.

\begin{tabular}{|c|c|c|c|c|c|c|}
\hline Treatment & FYM & Biochar & Compost & Vermi-compost & Mineral Fertil. & Mean (B) \\
\hline \multicolumn{7}{|c|}{ First season 2018} \\
\hline $60 \%$ of ETc & $1.22 \mathrm{jk}$ & $1.43 \mathrm{~h}$ & $1.42 \mathrm{~h}$ & $1.95 \mathrm{c}$ & $1.38 \mathrm{i}$ & $1.48 \mathrm{~B}$ \\
\hline $80 \%$ of ETc & $1.23 \mathrm{j}$ & $2.07 \mathrm{~b}$ & $1.68 \mathrm{e}$ & $2.16 \mathrm{a}$ & $1.73 \mathrm{~d}$ & $1.77 \mathrm{~A}$ \\
\hline $100 \%$ of ETc & $0.89 \mathrm{k}$ & $1.65 \mathrm{f}$ & $1.22 \mathrm{jk}$ & $1.70 \mathrm{e}$ & $1.56 \mathrm{~g}$ & $1.40 \mathrm{~B}$ \\
\hline Mean (A) & $1.12 \mathrm{D}$ & $1.72 \mathrm{~B}$ & $1.44 \mathrm{C}$ & $1.93 \mathrm{~A}$ & $1.56 \mathrm{C}$ & \\
\hline \% Increase or decrease & -28.2 & +10.3 & -7.69 & +23.7 & $\mathbf{0 . 0}$ & \\
\hline \multicolumn{7}{|c|}{ Second season 2019} \\
\hline $60 \%$ of ETc & $1.09 \mathrm{j}$ & $1.56 \mathrm{~d}$ & $1.42 \mathrm{f}$ & $1.78 \mathrm{~b}$ & $1.48 \mathrm{e}$ & $1.47 \mathrm{~A}$ \\
\hline $80 \%$ of ETc & $1.42 \mathrm{f}$ & $1.80 \mathrm{~b}$ & $1.36 \mathrm{~h}$ & $1.89 \mathrm{a}$ & $1.60 \mathrm{c}$ & $1.62 \mathrm{~A}$ \\
\hline $100 \%$ of ETc & 0.561 & $1.32 \mathrm{i}$ & $0.88 \mathrm{k}$ & $1.33 \mathrm{i}$ & $1.41 \mathrm{~g}$ & $1.10 \mathrm{~B}$ \\
\hline Mean (A) & $1.02 \mathrm{E}$ & $1.56 \mathrm{BC}$ & $1.22 \mathrm{D}$ & $1.67 \mathrm{~A}$ & $1.50 \mathrm{C}$ & \\
\hline \% Increase or decrease & -32.0 & +4.00 & -18.7 & +11.3 & $\mathbf{0 . 0}$ & \\
\hline
\end{tabular}

Table-8: Total cost of production and gross return analysis of lettuce plants due to different treatments in the two studied seasons of 2018 and 2019.

\begin{tabular}{|c|c|c|c|c|c|c|c|c|c|c|c|}
\hline \multirow{3}{*}{\multicolumn{2}{|c|}{ 計 }} & \multicolumn{5}{|c|}{ First season 2018} & \multicolumn{5}{|c|}{ Second season 2019} \\
\hline & & \multirow{2}{*}{$\begin{array}{l}\text { Total } \\
\text { yield }\end{array}$} & \multirow{2}{*}{$\begin{array}{c}\begin{array}{c}\text { Total } \\
\text { revenue }\end{array} \\
\text { LE }\end{array}$} & \multirow{2}{*}{$\begin{array}{c}\begin{array}{c}\text { Total cost } \\
\text { of }\end{array} \\
\text { production }\end{array}$} & \multirow{2}{*}{$\begin{array}{c}\begin{array}{c}\text { Gross } \\
\text { margin }\end{array} \\
\text { LE }\end{array}$} & \multirow[t]{2}{*}{ BCR } & $\begin{array}{l}\text { Total } \\
\text { yield }\end{array}$ & $\begin{array}{c}\text { Total } \\
\text { revenue }\end{array}$ & $\begin{array}{c}\text { Total cost } \\
\text { of }\end{array}$ & $\begin{array}{c}\text { Gross } \\
\text { margin }\end{array}$ & \multirow[t]{2}{*}{ BCR } \\
\hline & & & & & & & Tons & LE & LE & $\mathbf{L E}$ & \\
\hline \multirow{5}{*}{$\begin{array}{c}60 \% \text { of } \\
\text { ETc }\end{array}$} & FYM & 1.02 & 2035 & 1393 & 643 & 1.46 & 0.94 & 1889 & 1417 & 473 & 1.33 \\
\hline & Biochar & 1.19 & 2375 & 1480 & 895 & 1.60 & 1.36 & 2714 & 1506 & 1208 & 1.80 \\
\hline & Compost & 1.18 & 2354 & 1418 & 936 & 1.66 & 1.23 & 2468 & 1442 & 1026 & 1.71 \\
\hline & $\begin{array}{c}\text { Vermi- } \\
\text { compost }\end{array}$ & 1.62 & 3236 & 1543 & 1693 & 2.10 & 1.55 & 3092 & 1570 & 1523 & 1.97 \\
\hline & $\begin{array}{l}\text { Mineral } \\
\text { Fertil. }\end{array}$ & 1.15 & 1150 & 1355 & -205 & 0.85 & 1.28 & 1284 & 1378 & -94 & 0.93 \\
\hline \multirow{5}{*}{$\begin{array}{c}80 \% \text { of } \\
\text { ETc }\end{array}$} & FYM & 1.37 & 2736 & 1403 & 1334 & 1.95 & 1.64 & 3282 & 1427 & 1855 & 2.30 \\
\hline & Biochar & 2.30 & 4591 & 1490 & 3101 & 3.08 & 2.09 & 4173 & 1516 & 2657 & 2.75 \\
\hline & Compost & 1.86 & 3714 & 1428 & 2286 & 2.60 & 1.58 & 3152 & 1452 & 1700 & 2.17 \\
\hline & $\begin{array}{c}\text { Vermi- } \\
\text { compost }\end{array}$ & 2.39 & 4784 & 1553 & 3232 & 3.08 & 2.19 & 4376 & 1580 & 2796 & 2.77 \\
\hline & $\begin{array}{c}\text { Mineral } \\
\text { Fertil. }\end{array}$ & 1.92 & 1915 & 1365 & 550 & 1.40 & 1.85 & 1855 & 1389 & 466 & 1.34 \\
\hline \multirow{5}{*}{$\begin{array}{l}100 \% \\
\text { of ETc }\end{array}$} & FYM & 1.23 & 2460 & 1413 & 1048 & 1.74 & 0.81 & 1611 & 1437 & 174 & 1.12 \\
\hline & Biochar & 2.29 & 4573 & 1500 & 3073 & 3.05 & 1.90 & 3805 & 1526 & 2279 & 2.49 \\
\hline & Compost & 1.69 & 3384 & 1438 & 1947 & 2.35 & 1.27 & 2535 & 1463 & 1073 & 1.73 \\
\hline & $\begin{array}{l}\text { Vermi- } \\
\text { compost }\end{array}$ & 2.35 & 4697 & 1563 & 3135 & 3.01 & 1.92 & 3847 & 1590 & 2257 & 2.42 \\
\hline & $\begin{array}{l}\text { Mineral } \\
\text { Fertil. }\end{array}$ & 2.17 & 2167 & 1375 & 792 & 1.58 & 2.04 & 2043 & 1399 & 644 & 1.46 \\
\hline
\end{tabular}

Chemical production of one ton of lettuce $=1000 \mathrm{LE}$ per total area $\left(540 \mathrm{~m}^{2}\right)$; organic production of one ton of lettuce $=2000 \mathrm{LE}$ per total area $\left(540 \mathrm{~m}^{2}\right) .1 \$=15.60 \mathrm{LE}$ with today price.

\section{Water use efficiency (WUE)}

Data in Table 7 showed values of WUE under the effect of different irrigation water levels and fertilizers during the two studied seasons of 2018 and 2019. The highest value of the WUE was obtained due to applying the treatment of $80 \%$ of ETc followed by $60 \%$ of ETc. These results agree with those obtained by Bozkurt and Mansuroglu (2011) on lettuce plants. Regarding the effect of different fertilizer treatments on WUE, data showed that there were significant differences among treatments, applying vermi-compost led to increase WUE by 
about 23.7 and $11.3 \%$ over than control (applying mineral fertilizers), followed by biochar by about 10.3 and $4.0 \%$, during the two tested seasons, respectively. On the other hand, applying compost led to decrease WUE by about 7.69 and $18.7 \%$ less than control, followed by FYM by about 28.2 and $32.0 \%$, during the two tested seasons, respectively. Regarding the interaction between irrigation levels and fertilizer treatments, the highest WUE was obtained by $80 \%$ of ETc combined with vermicompost. Importance of organic fertilizers for better yield and maximize the efficiency use of water could be attributed to the role of them in improving the crop resistance to water stress by improving soil physical, chemical, and biological properties as well as supplying plants by macro- and micro-nutrients (Abdrabbo et al., 2015; Mostafa et al., 2019).

\section{Benefit to cost ratio (BCR)}

Data in Table 8 showed values of the benefit-cost ratio (BCR) due to applying the different treatment combinations in the two studied seasons of 2018 and 2019. The highest values (3.08 and 2.77) were obtained owing to applying the treatment of vermicompost $+80 \%$ of ETc during the two seasons, respectively. The lowest BCR values (0.85 and 0.93) were recorded due to applying the treatment of mineral fertilizers $+60 \%$ of ETc during the two seasons, respectively. These results agree with those obtained by Hashem and Abd-Elrahman (2016) on the benefits of applying organic fertilizers, compared to mineral fertilizers. Also, the results are in line with those obtained by Patil et al. (2013) on lettuce plants under different irrigation intervals and $\mathrm{N}$ application rates

\section{Conclusion}

The reuse of organic materials leads to mitigate $\mathrm{CO}_{2}$ emission and sequestrates $\mathrm{C}$ into the soil, which increase soil fertility, nutrient availability, and sustainable production. Using organic fertilizers especially vermi-compost encouraged the growth and improved yield of lettuce plants. Applying 80\% of ETc with vermi-compost was the best combination treatment, while increasing irrigation dose led to decrease water use efficiency. This treatment of combination gave the highest BCR, while the lowest ones were recorded by applying the treatment of mineral fertilizers $+60 \%$ of ETc during the two studied seasons, which focus the light on the benefits of applying organic fertilizers, compared to mineral ones.

Disclaimer: None.

Conflict of Interest: None.

Source of Funding: None.

\section{References}

Abdrabbo MAA, Hashem FA, Abul-Soud MA and Abd-Elrahman Shaimaa H, 2015. Sustainable production of cabbage using different irrigation levels and fertilizer types affecting some soil chemical characteristics. Int. J. Plant Soil Sci. 8(1): 1-13.

Asaduzzaman MD, Shamima S and Arfan MD, 2010. Combined effect of mulch materials and organic manure on the growth and yield of lettuce. J. Agric. Environ. Sci. 9(5): 504-508.

Bozkurt S and Mansuroglu GS, 2011. Lettuce yield responses to different drip irrigation levels under open field condition. J. Cell Plant Sci. 2(2): 1218.

Chaichi MR, Ansari M, Bhandari S and Raheja A, 2020. Physiological and economic aspects of lettuce production under deficit water and nitrogen conditions. Adv. Agric. Hort. Entomol: AAHE-135.

Chapman HD and Pratt PF, 1961. Methods of Analysis for Soils, Plants and Waters. Division of Agric. Sci., Berkeley Univ., California, USA, pp. 150-152.

Cimmyt, 1988. From Agronomic Data to Farmer Recommendation: An Economic Workbook DF: pp. 31-33.

El-Bassi L, Azzaz AA, Jellali S, Akrout H, Marks EAN, Ghimbeu CM and Jeguirim M, 2021. Application of olive mill waste-based biochars in agriculture: Impact on soil properties, enzymatic activities and tomato growth. Sci. Total Environ. 755: 1-11.

Elsharkawi HM, Tojo S, Chosa T, Malhat FM and Youssef AM, 2018. Biochar-ammonium phosphate as an uncoated-slow-release fertilizer in sandy soil. Biomass Bioener. 117: 154-160.

FAO, 1982. Crop Water Requirements Irrigation and Drainage. Paper No. 24, Rome, Italy.

FAO, 2012. Crop Yield Response to Water. Paper No. 33, Rome, Italy.

Han L, Sun K, Yang Y, Xia X, Li F, Yang Z and Xing B, 2020. Biochar's stability and effect on 
the content, composition and turnover of soil organic carbon. Geoderma, 364: 114184. https://doi.org/10.1016/j.geoderma.2020.114184

Hashem FA, Abdrabbo MAA, Abou-El-Hassan S and Abul-Soud MA, 2014. Maximizing water use efficiency via different organic mulches and irrigation levels. Res. J. Agric. Biol. Sci. 10(2): 109-117.

Hashem FA and Abd-Elrahman SH, 2016. Soil chemical characteristics and growth of broccoli and cauliflower plants as affected by liquid organic fertilizers and irrigation water levels. Global J. Adv. Res. 3(10): 881-895.

Ibn Ferjani A, Jellali S, Akrout H, Limousy L, Hamdi $\mathrm{H}$, Thevenin $\mathrm{N}$ and Jeguirim M, 2020. Nutrient retention and release from raw exhausted grape marc biochars and an amended agricultural soil: Static and dynamic investigation. Environ. Technol. Innov. 19: 100885. https://doi.org/10.1016/j.eti.2020.100885

Kere GM, Nyanjage MO, Liu M and Nyalala SPO, 2003. Influence of drip irrigation schedule and mulching materials on yield and quality of greenhouse tomato (Lycopersicon esculentum Mill. 'Money Maker'). Asian J. Plant Sci. 2(14): 1052-1058.

Khorram MS, Zhang Q, Lin D, Zheng Y, Fang H and Yu Y, 2016. Biochar: A review of its impact on pesticide behavior in soil environments and its potential applications. J. Environ. Sci. 44: 269279. https://doi.org/10.1016/j.jes.2015.12.027

Klute A, 1986. Methods of Soil Analysis, part I, $2^{\text {nd }}$ ed., Wisconsin, Madison, USA.

Lone AH, Najar GR, Ganie MA, Sofi JA and Tahir A, 2015. Biochar for sustainable soil health: A review of prospects and concerns. Pedosphere. 25(5): 639-653.

Magwaza LS and Opara UL, 2015. Analytical methods for determination of sugars and sweetness of horticultural products: A review. Sci. Hort. 184: 179-192. https://doi.org/10.1016/j.scienta.2015.01.001

Minolta, 1989. Chlorophyll meter SPAD-502, Instruction Manual. Minolta Co., Ltd., Radiometric Instruments Operations, Osaka, Japan.

Mostafa HHA, Hefzy M, Zahran MMAA and Refai EFS, 2019. Response of lettuce (Lactuca sativa
L.) plants to application of compost levels under various irrigation regimes. Middle East J. Agric. Res. 8(2): 662-674.

Munnoli PM, Teixeira da Silva JA and Bhosle S, 2010. Dynamics of the soil-earthworm-plant relationship: A review. Dynamic Soil, Dynamic Plant. 4(1): 1-21.

Obia A, Mulder J, Martinsen V, Cornelissen G and Borresen T, 2016. In-situ effects of biochar on aggregation, water retention and porosity in lighttextured tropical soils. Soil Tillage Res. 155: 3544. https://doi.org/10.1016/j.still.2015.08.002

Page AL, Miller RH and Keeney DR, 1982. Methods of Soil Analysis, part II, $2^{\text {nd }}$ ed., Wisconsin, USA.

Patil T, Singh M, Khanna M, Singh DK and Hasan M, 2013. Response of lettuce (Lactuca sativa L.) to trickle irrigation under different irrigation intervals, $\mathrm{N}$ application rate and crop geometry. Indian J. Agric. Econ. 68(4): 573-582.

SAS Institute, 2006. The SAS system for windows; Statistical Analysis System Institute Inc., Cary, North Carolina, USA.

Soong JL, Dam M, Wall DH and Cotrufo MF, 2017. Below-ground biological responses to pyrogenic organic matter and litter inputs in grasslands. Functional Ecol. 31: 260-269. https://doi.org/10.1111/1365-2435.12693

\section{Contribution of Authors}

Abd El-Fattah DA: Designed research methodology and collected data

Hashem FA: Designed research methodology, data analysis and interpretation

Abd-Elrahman SH: Data analysis and interpretation, literature review, manuscript writing and approval

Walker DJ and Bernal MP, 2004. Plant mineral nutrition and growth in a saline Mediterranean soil amended with organic wastes. Commun. Soil Sci. Plant Anal. 35(17 \& 18): 2495-2514.

Watanabe FC and Olsen SR, 1965. Test of an ascorbic acid method for determining phosphorus in water and $\mathrm{NaHCO}_{3}$ extracts from soils. Soil Sci. Soc. Am. Proc. 29: 677-678. 